\title{
AN IOWA LAND "BARGAIN" A CENTURY AGO
}

(The original of this letter is filed in the Manuscript Division of the Iowa State Department of History and Archives, dated October 19, 1843, addressed to Anson Sperry, Chicago, Ill., afterwards residing at Marengo, Ill., from his sister, Mrs. Elizabeth Sperry Roberts, wife of Iowa's Lieutenant Colonel, 1844-46, and Mexican War hero.)

Fort Madison, Oct. 19, 1843

Dear Brother: Perhaps you think we have been negligent in writing, but I am not quite prepared to plead guilty to the charge, for I have been waiting from day to day in hopes to know if we conclude to stay here or not. But I am as wise now as when we first arrived here.

When we arrived here $\mathrm{Mr}$. R. found a letter from President Wylie of the Indiana institution at Bloomington, saying that he (Mr. R) had been recommended by Bishop Kemper to the University as professor of mathematics, salary $\$ 1,000$ a year cash or town scrip, which was as good as $\$ 1,100$ cash. He desired him to come on, or send testimonials in time for a meeting of the board which was to convene at a certain period. $M r$. $R$ had no means of procuring testimonials here, and answered the letter immediately, but not in time for the meeting of the board. The letter had probably lain here some time, and there was but a week before the time appointed for the meeting and I believe ten days is the time required for a letter to reach there. $\mathrm{He}$ (Mr. R) was obliged to refer him to gentlemen East for testimonials and the consequent delay is probably the reason we do not hear, tho' we are in daily expectation of a letter. I think (Mr. R.) quite indifferent about going. There seems so good an opening in the territory for young men.

There seems an opening, too, for a good investment for R's $\$ 100$ which belongs to his name. I will try and tell you about it. A lawyer here, Mr. Reeves, had been employed by a creditor of a half-breed to collect a personal debt of said half-breed by an execution on his claim. It had been sold-or rather he bought it in on behalf of the creditor for $\$ 225$. It is an entire claim 
of 1125 acres all lying within three or four miles of Old Fort Des Moines, except fifteen town lots in the town of Keokuk, which is at the foot of the rapids and two in Nashville, another town on the rapids. The land is most of it under improvement, and several small log houses on them, and we are told that the settlers will be very glad to sell their improvements for a portion of the land and will sell very low, too. Mr. Reeves, the lawyer, already ownes a large amount of land in the same tract, as much as 20,000 acres and does not care to own more; besides there is a law forbidding lawyers to take advantage of such opportunities, connected with their clients. He has a sheriff's deed and tax title to the claim and there is but one drawback, but I believe that is not deemed a serious one. There was a law passed that enough land should be sold to defray the expenses of surveying and dividing the tract, a debt due the commissioners and they sold the whole tract to liquidate that debt. It was bought in by Mr. Reeves, another lawyer here, for $\$ 2,000$ or $\$ 3,000$. Mr. R. says he cannot hold it on that purchase, and aware of the fact, relinquished to settlers his claim upon their paying a portion of their share of the money he spent in buying it in and something more for time and money spent, and he makes money at that. Another objection is, its proximity to Nauvoo, which is directly opposite and they are said to be very troublesome as thieves and trespassers.

The opportunity is not known generally and $\mathrm{Mr}$. R. wishes it kept quiet until we can communicate with $\mathrm{Pe}$, [Pa] and he hopes to be able to join in the purchase. There is an opportunity till March of judgment creditors, if there are any, to redeem at 25 per cent, but in that case it will be a handsome advance on his money. Perhaps $R$. will like your opinion before he decides. We rode past some of the land yesterday and there is none finer in the world. One farm lies on the shore of the Mississippi and takes in an island which lies very near. the main land.

Of our journey over here nothing of moment occurred. 
We had pleasant weather and came on till Friday as well as when we left on that day. Our dear little Rufus was taken more unwell, and continued so until we arrived now (Saturday noon) tho' not alarmingly so. We immediately called in a physician however, and he continued to fail until Wednesday morning about 4 o'clock in the morning when he breathed his last. It is a great trial to lose so dear an one, yet I could not ask him back; for is he not an angel and unmoved from [by] the trials and vexations of this life? And when I think of the shortness and uncertainty of human lives and the great work we have to do in preparing for eternity, the obstacles we have to contend with in our own wayward hearts, - the certainty I feel that my two children are in the haven to which we all ought to be bound-seems to call for gratitude rather than repining. Yet is the flesh weak-God grant when our short life is over we may join many dear friends whom we have a realizable hope are with the saints on high.

Could I hear that $\mathrm{Pe}[\mathrm{Pa}]$ had made up his mind to the resolutions you have adopted how happy should I feel. I wish you would write him. I hope to hear that Cousin Mark has at least concluded to live for eternity rather than time. He has had a loud call as well as the rest of us, "be Ye also ready for in such an hour as Ye know not the Son of Man cometh."

Ma has had your pantaloons ready and been waiting some time for an opportunity to send them. One of our lawyers is going to Bloomington this territory to court next week and I am told Mr. Butterfield of your place will be there also. Ma will send the package to him. I should be glad if you have not despatched the box already, if you could do so by Mr. Butterfield, if he come by stage taking a receipt of the stage proprietor and request them to send it from there the first boat that comes down. If you cannot do that send it to Rock Island or Rockingham (I believe they are one and the same place). I am told that a stage runs from Chicago there in two days, and also that there are empty wheat 
trains going back all the time and the box directed to the care of N. B. Buford, Rock Island, will be forwarded to us immediately. Unless the box will come very soon by a wheat train it is not best to trust it, for if we go to Indiana it will be important for us to get it soon. Please do not delay forwarding it.

Our other boxes are here and we are waiting with great impatience to hear from Indiana to go to housekeeping. Mr. R. says he will commence next week anyhow if he does not hear. Ma left a linen handkerchief where we dined the day we left Chicago at Geo. Bill's tavern. We asked Ira Buck to get it and carry it to you. Did you get it? Ma thinks you had better take that frock coat out of the box and get some woman to mend it. It is so seldom we find an opportunty to sending to you. Ma will write next week when she sends the package and we shall probably know if we go or stay by that time.

We have been to Nauvoo since we came. I presume Ma will write you about it when she writes you etc. I have not room. Write us soon and tell us all about everybody. Love to Cousin Mark and Coz. Libbie. Mr. R. joins me also wishes to be remembered to you.

Yours sister 
Copyright of Annals of Iowa is the property of State of Iowa, by \& through the State Historical Society of Iowa and its content may not be copied or emailed to multiple sites or posted to a listserv without the copyright holder's express written permission. However, users may print, download, or email articles for individual use. 